\title{
Salinity Tolerance in Argentinean Population of Bromus catharticus. Variability and Direct and Indirect Effects on Seedling Characters
}

\author{
Monica Beatriz Aulicino*, Monica Beatriz Collado, Hernan Barca, Maria del Carmen Molina \\ Instituto Fitotécnico de Santa Catalina, Facultad de Ciencias Agrarias y Forestales, Universidad Nacional de La Plata, La Plata, \\ Argentina \\ Email: *maulicino@agro.unlp.edu.ar
}

How to cite this paper: Aulicino, M.B., Collado, M.B., Barca, H. and Molina, M.C. (2020) Salinity Tolerance in Argentinean Population of Bromus catharticus. Variability and Direct and Indirect Effects on Seedling Characters. American Journal of Plant Sciences, 11, 2043-2058.

https://doi.org/10.4236/ajps.2020.1112144

Received: October 20, 2020

Accepted: December 14, 2020

Published: December 17, 2020

Copyright $\odot 2020$ by author(s) and Scientific Research Publishing Inc. This work is licensed under the Creative Commons Attribution International License (CC BY 4.0).

http://creativecommons.org/licenses/by/4.0/

\begin{abstract}
The aim of this research was to evaluate the salinity tolerance in prairie grass populations at the seedling stage quantifying the variability and the influence of physiological traits related to it. Salinity tolerance, in Bromus catharticus Vahl (prairie grass) populations collected in different environments of the Pampean Phytogeography region (Argentine) was evaluated at the seedling stage, using controlled condition of temperature and light. It was adopted a completely randomized design using 3 plots with three plants each one per population and two levels of treatment: $0 \mathrm{mM}$ and $100 \mathrm{mM} \mathrm{NaCl}$. Morphological, biomass and membrane stability root and shoot traits were studied. A factorial ANOVA with interaction was estimated. Then one way ANOVA for all seedling traits in both treatments allowed estimating variance components, coefficient of genotypic determination (CGD) and variation index (VI). Comparisons between populations were made using Tukey test (at 5\% of probability). Phenotypic correlations among traits were calculated and then a path coefficient analysis separated direct and indirect effects at 100 and $0 \mathrm{mM}$ $\mathrm{NaCl}$. No significant interactions "Population $\times$ Treatment" were found for any character. The saline stress caused a pairing in the population means for the most traits. Coefficients of variation were mainly higher when the seedlings grew without stress $(0 \mathrm{mM})$ because it allowed a greater potential genotypic expression. The absence of significant interactions denotes a good homeostatic capacity of the prairie grass facing that abiotic stress. Leaf length, shoot length and root dry matter were the variables with the largest direct and indirect effects. Our results showed an increase for them at salt and demonstrated intraspecific variation, possibly in relation with the origin sites. Plants under stress showed a marked resilience, in order to quickly restore the same biomass allocation patterns that occur in non-stress environment.
\end{abstract}




\section{Keywords}

Bromus catahrticus, Prairie Grass, Salinity Tolerance, Population Genetic Variability, Path Coefficient Analysis

\section{Introduction}

In recent years an agricultural process has happened due to the high demand for grains with a strong price increase. It has led to a redistribution of beef cattle to marginal areas where soils have low aptitude and excess soluble salt. This situation will tend to worsen in places where climate change alters the precipitation/evapotranspiration balance and where agricultural practices lead to secondary salinization [1]. Argentina is the third country in the world with a largest area of soil affected by halomorphic features [2], after Russia and Australia [3] [4] [5]. Abiotic stress soils limit growth, biomass accumulation and productivity in most crops and forage around the world. Salt stress causes a high energetic cost because of disturbances in physiological, biochemical, molecular processes in the plant [6]. Especially salt stress reduces forage growth and yield, generating a relevant economic cost to farmers [7]. Salinity affects biomass production and alters the partition of photo assimilates between different parts of plants. This behavior could be due to osmotic, toxic and nutritional effects. Therefore, differences in the degree of tolerance of species or cultivars depend on the efficiency of morphological and physiological mechanisms, which increase the capacities of plants to face the increase in salt concentration in the soil [8] [9]. Other costs are related to poor stand establishment and/or mature plants and plant's ability to resist a second stress as biotic ones [10].

Bromus catahrticus Vahl. (Prairie grass or Rescue grass) is an annual native species that grows naturally in the Argentine Pampas, Uruguay and South of Brazil and North Central area of Chile. It is widely used in mixed pastures consociated with legumes and it is considered the most important forage grass due to a high certified seed production in Argentina [11]. In the future, the forage market must count on varieties capable of growing in environments with limitations. This requires the evaluation of new genetic sources for salt tolerance, and more efficient techniques to identify and localize tolerant genes by QTLs analysis, which could be used to introduce into cultivars by biotechnology [12].

Breeding for the selection of stress-tolerance as salinity has used different growth parameters like shoot and root length and dried mass [13]. Several other physiological attributes have been reported as being reliable indicators of tolerant germplasm in selection programs. These include seed germination, the degree of electrolyte leakage (cell membrane stability, CMS) from salinity-damaged leaf cells and the water relations of plants [14] [15].

The path analysis methodology has been frequently used by plant breeders to assist in identifying traits that are useful as selection criteria to improve yield. 
The path coefficient is a standardized partial regression coefficient which measures the direct influence of a predictor variable on the response variable [16]. The method allows the partition of the correlation coefficients into direct and indirect effects, applied to a causal diagram built according to logical basis.

Selection programs used in forage species intended to be sown in marginal conditions should prioritize adaptive capacity rather than high yields. In addition, it should be taken into account that there are negative relationships between characters that confer adaptability and those related to performance [17]. It is convenient to select populations adapted to a particular ecological niche, rather than trying changes in germplasm adaptability. The Pampa (Buenos Aires Province) offer a broad diversity of habitats with saline, alkaline and sandy soils. A patchy morphological variation model, genetically adapted to macro and micro environmental conditions, was detected in B. catharticus populations, collected at the Pampas region [18] [19]. Germplasm collected from saline habitats could ensure the identification of genes tolerant to this stress. In other grass species, variability for physiological traits related to stress tolerance is associated with population origin [20].

The aim of this research was to evaluate the salinity tolerance in prairie grass populations at the seedling stage quantifying the variability and the influence of physiological traits related to it.

\section{Materials and Methods}

\subsection{Plant Material}

Wild prairie grass populations (B.catharticus) were collected on six locations of the Pampas region at Buenos Aires Province, Argentine. The collecting expeditions covered a wide range of habitat conditions, crossing the Salado river depression, from Cañuelas to Bolivar (Table 1). A minimum of 50 matured

Table 1. Geographic distribution and habitat of six sampled localities in the Buenos Aires Province, Argentine.

\begin{tabular}{|c|c|c|c|c|}
\hline Number & $\begin{array}{l}\text { Collection } \\
\text { sites }\end{array}$ & Latitude & Longitude & Habitat \\
\hline 1 & Lobos & $\mathrm{S} 35^{\circ} 18^{\prime}$ & $\mathrm{W} 59^{\circ} 19^{\prime}$ & $\begin{array}{l}\text { Ruderal road side (Route } \mathrm{n}^{\circ} 205 \text { ) to } \\
2 \mathrm{~km} \text { away Rio Salado. }\end{array}$ \\
\hline 2 & R. Pérez & $\mathrm{S} 35^{\circ} 26^{\prime}$ & $\mathrm{W} 59^{\circ} 40^{\prime}$ & Ruderal road side (Route $n^{\circ} 205$ ). \\
\hline 3 & Saladillo & $\mathrm{S} 35^{\circ} 44^{\prime}$ & $\mathrm{W} 60^{\circ} 04^{\prime}$ & $\begin{array}{l}\text { Ruderal road side (Route } n^{\circ} 205 \text { ). } \\
\text { Nearly away a drainage channel. }\end{array}$ \\
\hline 4 & Azul & $\mathrm{S} 36^{\circ} 54^{\prime}$ & $\mathrm{W} 59^{\circ} 49^{\prime}$ & $\begin{array}{l}\text { Natural field. } \\
\text { Crossroad routes } n^{\circ} 6 \text { and } n^{\circ} 226 \text {. }\end{array}$ \\
\hline 5 & Tandil & $\mathrm{S} 37^{\circ} 34^{\prime}$ & $\mathrm{W} 59^{\circ} 05^{\prime}$ & $\begin{array}{l}\text { Ruderal road side (Route } \mathrm{n}^{\circ} 226 \text { ). } \\
\text { Before crossroad with Route } \mathrm{n}^{\circ} 74 \text {. }\end{array}$ \\
\hline 6 & Ayacucho & $\mathrm{S} 37^{\circ} 22^{\prime}$ & W $58^{\circ} 49^{\prime}$ & $\begin{array}{c}\text { Ruderal road side, } \\
\text { Crossroads } n^{\circ} 29 \text { and } n^{\circ} 74 .\end{array}$ \\
\hline
\end{tabular}


reproductive tillers were sampled from an ecological area of 100 to $1000 \mathrm{~m}^{2}$. It was ensured that each tiller belonged to a different individual [21]. From each panicle, 10 cariopses were taken out to make a homogeneous genetic pool for each population. Samples from those seeds have now been conserved at the Germplasm Bank of Instituto Fitotécnico de Santa Catalina, Facultad de Ciencias Agrarias y Forestales, Universidad Nacional de La Plata.

\subsection{Growth Conditions and Experimental Design}

Thirty caryopses from each population were germinated in Petri dishes with moistened filter paper in a dark incubator at $26^{\circ} \mathrm{C}$ during five days. During the sixth day of germination, three uniformly germinated seedlings were transferred to pots containing "perlite". A completely randomized design with 3 plots with three plants each one per population and treatment was adopted ( 9 plants per populations and 54 total plot per treatment). These pots were put into trays containing half-strength Hoagland's nutrient solution and 4 days later started the salt additions. The final concentration was reached by a gradual increment of $25 \mathrm{mM} \mathrm{NaCl}$ every two days [13] [22] [23]. Then, the solutions were renewed every three days. All conditions were maintained constant during the growth period. The trial was carried out in a controlled room at $25^{\circ} \mathrm{C}$, with $10-14 \mathrm{~h}$ day-night length. After 28 days of treatment, the seedlings were harvested.

\subsection{Measurement}

The following traits were measured at the end of experimentation (four weeks): Number of leaves (NL); Leaf 3rd length (LL), in cm; Shoot length (SL), in cm; Root length (RL), in cm; Separately shoots and roots per population were cut and after drying in an oven at $70^{\circ} \mathrm{C}$ until constant weight was achieved and then Shoot dry mass (SDM) and Root dry mass (RDM) were calculated.

\subsection{Cell Membrane Stability (MS)}

It was estimated on the third leaf and root with a conductometer (Consort C931) and expressed in electrical conductivity $(\mu \mathrm{S} / \mathrm{cm})$. A piece of leaf and root $(1 \mathrm{~cm})$ was cut, weighted and washed with distilled water to remove the solution from tissue, then the samples were separately immersed in $10 \mathrm{ml}$ of distilled water and placed for incubation for $24 \mathrm{~h}$ at $5^{\circ} \mathrm{C}$. After incubation samples were equilibrated to room temperature. Then, the conductivity of the medium was recorded (EC1), the samples were autoclaved for $15 \mathrm{~min}$ to kill all tissues, and after cooled to room temperature, the conductivity of the solutions was read again (EC2). The ratio EC1/EC2 estimated separately for root and leaf constituted the cell membrane stability for root (RMS) and leaf (LMS), respectively [24] [25].

\subsection{Statistical Analysis and Genetic Model}

At first, the data was subjected to the analysis factorial of variance to prove differences between populations $(G)$, Treatments $(E)$ and the interaction $G \times$ E. It 
was used a mixed model with population as random effect and treatments as fixed effects.

Then a one way ANOVA for all seedling traits measured under salt stress (100 $\mathrm{mM})$ and non stress $(0 \mathrm{mM})$ allowed estimating variance components according to [26]. The statistical model was:

$$
Y_{i j}=\mu+\alpha_{i}+\varepsilon_{i j}
$$

where: $\mu$ : General mean. $Y_{i j}=$ observation on the $i^{\text {th }}$ genotype in the $f^{\text {th }}$ replication; $\alpha_{i}$ : random effect attributed to $i^{\text {th }}$ genotype $(i=1,2,3,4,5,6)$; and $\varepsilon_{i j}$ : experimental error attributed to $Y_{i j}$ observation.

Using the population means square (PMS) and the error means squares (EMS), the following genetic parameters were estimated: Genotypic variability $\left(\sigma_{g}^{2}\right)=$ PMS - EMS/9 (number of replications); Phenotypic variance $\left(\sigma_{P}^{2}\right)=\sigma_{g}^{2}$ + EMS. Coefficient of genotypic determination (CGD) $=\sigma_{g}^{2} / \sigma_{P}^{2}$. Coefficient of experimental variation $(\mathrm{CEV})$ is calculated as $(\mathrm{EMS} / 9) / \mathrm{m} * 100)$. The variation index: Coefficient of genotypic variation $(\mathrm{CGV})=\frac{100 * \sqrt{\hat{\sigma}_{g}^{2}}}{m}$ (where $m$ is the general mean). Variation index (VI) $=\mathrm{CGV} / \mathrm{CEV}$.

Comparisons between populations were made using Tukey test at 5\% of probability. Thus, phenotypic correlations among the different traits were separately estimated in both treatments, using the individual data [27].

Path coefficient analysis (PCA) was used to partition the correlation coefficients among variables into direct and indirect effects [16]. To apply the method of path coefficients, it is necessary to work within a logical cause-effect diagram construct with the traits considered (figure no shown). In the diagram adopted SDM is the dependent variable, RDM, NL, LL, SL and RL are the first-order variables; and RMS is the second-order variable. Schemes were constructed to consider the significance of the correlation coefficients between the variables ( $p<$ 0.05 ) and the better fit (Lower residue value). The phenotypic correlation coefficients were partitioned into direct and indirect effects according to the following set of linear equations:

$$
\begin{aligned}
& r_{A F}=\rho_{A F}+r_{A B}{ }^{*} \rho_{B F}+r_{A C}{ }^{*} \rho_{C F}+r_{A D}{ }^{*} \rho_{D F}+r_{A E}{ }^{*} \rho_{E F} \\
& r_{B F}=r_{A B}{ }^{*} \rho_{A F}+\rho_{B F}+r_{B C}{ }^{*} \rho_{C F}+r_{B D}{ }^{*} \rho_{D F}+r_{B E}{ }^{*} \rho_{E F} \\
& r_{C F}=r_{A C}{ }^{*} \rho_{A F}+r_{B C}{ }^{*} \rho_{B F}+\rho_{C F}+r_{C D}{ }^{*} \rho_{D F}+r_{C E}{ }^{*} \rho_{E F} \\
& r_{D F}=r_{A D}{ }^{*} \rho_{A F}+r_{D B}{ }^{*} \rho_{B F}+r_{D C}{ }^{*} \rho_{C F}+\rho_{D F}+r_{A E}{ }^{*} \rho_{E F} \\
& r_{E F}=r_{A E}{ }^{*} \rho_{A F}+r_{E B}{ }^{*} \rho_{B F}+r_{E C}^{*} \rho_{C F}+r_{E D}^{*} \rho_{D F}+\rho_{E F}
\end{aligned}
$$

where: (A): SL, (B): RL, (C): LL, (D): NL, (E): RDM and (F): SDM, and $r$ is the phenotypic linear correlation coefficient between two variables, $\rho$ is the path coefficient measuring direct effects and $r^{*} \rho$ is the measure of the indirect effect of one variable upon another [16]. Genetical analysis and path analysis were calculated with the computational program Genes [28]. 


\section{Results}

\subsection{Variability}

Two ways ANOVA with interaction were shown in Table 2. It was demonstrated significant differences between population for the most of variables, except $R L$ and NL. No significant interaction "Population $\times$ Treatment" was tested for any character. Significant differences between treatments $(100 \mathrm{mM}$ versus 0 $\mathrm{mM}$ ) were only proved for LMS and RDM.

The ANOVAS per treatment showed that the populations differed significantly for RMS, SL, LL, SDM and RDM when they grew without salt stress (0 $\mathrm{mM} \mathrm{NaCl}$ ), even if at $100 \mathrm{mM} \mathrm{Cl} \mathrm{Na}$ only differed for RMS, SL and LL (Table 3). Saline treatment means $(100 \mathrm{mM})$ were higher than those found at $0 \mathrm{mM}$ for some traits (Table 3). The genetic model showed that CGV, CDG and VI at 0 $\mathrm{mM} \mathrm{NaCl}$ had highest values than at $100 \mathrm{mM}$ for all seedling traits, with the exception of the RMS that reached a slightly lower value for CDG y VI due to a major CPV value (Table 3 ).

Tukey test to means comparison between populations was shown in Table 4 . Mayor variability was demonstrated at $0 \mathrm{mM}$. However, differential responses were also found in salt. Ayacucho presented the highest means for membrane stability attributes, and consequently it had lower rates of leaf and stem growth, determining a minor SDM at salt. The remaining populations presented means greater, although maintained a relative position similar to the ranking built at 0 $\mathrm{mM}$. It means that populations with better performance at $0 \mathrm{mM}$ also were the best at $100 \mathrm{mM}$. Saladillo and Tandil reached higher means and had a stable behavior in both treatments for the most variables and it confirmed the existence of homeostatic responses.

\subsection{Correlations}

At $0 \mathrm{mM}$, the significant correlation coefficients $(\mathrm{p}<0.05)$ had all positive signs. In contrast, at $100 \mathrm{mM} \mathrm{NaCl}$ the correlations presented both negative and positive signs (Table 5).

Table 2. Two way analysis of variance with interaction. Means Squares for Leaf cell membrane stability (LMS, ratio), Root cell membrane stability (RMS, ratio), Root length (RL, cm), Leaf length (LL, cm), Number leaf (NL, number), Shoot dry mass (SDM, mg) and Root dry mass (RDM, mg).

\begin{tabular}{cccccccccc}
\hline $\begin{array}{c}\text { Source of } \\
\text { variation }\end{array}$ & df & LMS & RMS & SL & RL & LL & NL & SDM & RDM \\
\hline $\begin{array}{c}\text { Treatments } \\
\text { (A) }\end{array}$ & 1 & $0.19^{* *}$ & $3 \times 10^{-3}$ & 26.91 & 2.93 & 4.01 & $2 \times 10^{-4}$ & 1843 & $3092^{* *}$ \\
$\begin{array}{c}\text { Population } \\
\text { (B) }\end{array}$ & 5 & $0.02^{*}$ & $0.04^{* *}$ & $80.51^{* *}$ & 50.35 & $50.64^{* *}$ & 0.55 & $7574^{*}$ & $1728^{* *}$ \\
A $\times$ B & 5 & 0.01 & 0.007 & 24.02 & 12.69 & 5.75 & 0.49 & 1829.9 & 81.3 \\
Error & 96 & 0.006 & 0.009 & 18.07 & 31.09 & 11.78 & 0.35 & 2565.1 & 349.79 \\
\hline
\end{tabular}

${ }^{*}$ Significant at the 0.05 probability level, ${ }^{*}$ Significant at the 0.01 probability level and ns not significant. 
Table 3. One way ANOVA Means Squares, Tukey test (at 5\%) for comparison of means between treatments, Coefficient of Phenotypic Variation (CPV), Coefficient of genotypic determination (CGD) and variation index (VI) for six prairie grass populations growth a $0 \mathrm{mM}$ and $100 \mathrm{mM} \mathrm{NaCl}$. Traits: Leaf cell membrane stability (LMS, ratio), Root cell membrane stability (RMS, ratio), Leaf length (LL, cm), Shoot length (SL, cm), Root length $(\mathrm{RL}, \mathrm{cm})$, Number leaf (NL, number), Shoot dry mass (SDM, mg) and Root dry mass (RDM, mg).

\begin{tabular}{cccccccccc}
\hline & \multicolumn{7}{c}{$0 \mathrm{mM} \mathrm{NaCl}$} \\
\hline Source of variation & gl & LMS & RMS & LL & SL & RL & NL & SDM & RDM \\
\hline Population & 5 & $0.02^{*}$ & $0.03^{*}$ & $27.1^{*}$ & $52.8^{*}$ & $39.7 \mathrm{~ns}$ & $0.8 \mathrm{~ns}$ & $6698.6^{*}$ & $1016.5^{*}$ \\
Residual & 48 & 0.01 & 0.01 & 8.3 & 17.9 & 49.2 & 0.4 & 2569.4 & 263.1 \\
mean & & $0.29 \mathrm{~b}$ & $0.56 \mathrm{a}$ & $26.11 \mathrm{a}$ & $33.49 \mathrm{a}$ & $26.35 \mathrm{a}$ & $6.04 \mathrm{a}$ & $190.6 \mathrm{a}$ & $73.4 \mathrm{~b}$ \\
CPV & & 27.29 & 19.98 & 11.03 & 12.63 & 26.63 & 9.75 & 26.60 & 22.10 \\
CDG & & 16.66 & 14.27 & 20.18 & 17.81 & 0.00 & 12.49 & 15.15 & 24.14 \\
VI & & 0.45 & 0.41 & 0.50 & 0.47 & & 0.38 & 0.42 & 0.56 \\
\hline Source of variation & gl & LMS & RMS & LL & SL & RL & NL & SDM & RDM \\
\hline Population & 5 & $0.01 \mathrm{~ns}$ & $0.02^{*}$ & $29.2^{*}$ & $51.72^{*}$ & $23.3 \mathrm{~ns}$ & $0.25 \mathrm{~ns}$ & $2,705.2 \mathrm{~ns}$ & $474.6 \mathrm{~ns}$ \\
Residual & 48 & 0.006 & 0.007 & 11.8 & 18.2 & 12.9 & 0.34 & 2560.8 & 226.5 \\
mean & & $0.38 \mathrm{a}$ & $0.55 \mathrm{a}$ & $26.49 \mathrm{a}$ & $34.49 \mathrm{a}$ & $26.68 \mathrm{a}$ & $6.04 \mathrm{a}$ & $198.8 \mathrm{a}$ & $84.0 \mathrm{a}$ \\
CPV & & 20.91 & 14.89 & 14.75 & 12.24 & 13.48 & 9.70 & 25.45 & 24.84 \\
CDG & 6.62 & 18.39 & 9.23 & 16.94 & 8.19 & 0 & 0.62 & 8.31 \\
VI & & 0.27 & 0.47 & 0.31 & 0.45 & 0.30 & & 0.08 & 0.30 \\
\hline
\end{tabular}

${ }^{\star}$ Significant at the 0.05 probability level, ${ }^{*}$ Significant at the 0.01 probability level and ns not significant. Different letters indicate significant differences between Treatments $(0 \mathrm{mM}$ vs $100 \mathrm{mM} \mathrm{Cl} \mathrm{Na}$, at $\mathrm{p}<0.05$ (Tukey's Test).

Table 4. Population mean comparison using Tukey test (p: 0.05) for six prairie grass populations seedling means. Leaf cell membrane stability (LMS, ratio), Root cell membrane stability (RMS, ratio), Shoot length (SL, cm), Root length (RL, cm), Leaf length (LL, $\mathrm{cm}$ ), Number leaf (NL, number), Shoot dry mass (SDM, mg) and Root dry mass (RDM, $\mathrm{mg})$.

\begin{tabular}{|c|c|c|c|c|c|c|c|c|}
\hline \multicolumn{9}{|c|}{$0 \mathrm{mM} \mathrm{NaCl}$} \\
\hline & LMS & RMS & LL & SL & $\mathrm{RL}$ & NL & SDM & $\mathrm{RDM}$ \\
\hline Lobos & $0.28 \mathrm{ab}$ & $0.58 \mathrm{ab}$ & $24.85 \mathrm{~b}$ & $31.25 \mathrm{~b}$ & $23.72 \mathrm{a}$ & $5.80 \mathrm{a}$ & $157.27 \mathrm{~b}$ & $58.61 \mathrm{~b}$ \\
\hline R. Perez & $0.28 \mathrm{ab}$ & $0.52 \mathrm{ab}$ & $24.56 \mathrm{~b}$ & $30.95 \mathrm{~b}$ & $23.93 \mathrm{a}$ & $5.85 \mathrm{a}$ & $156.27 \mathrm{~b}$ & $63.20 \mathrm{~b}$ \\
\hline Saladillo & $0.37 \mathrm{a}$ & $0.64 \mathrm{a}$ & $27.94 \mathrm{ab}$ & $35.74 \mathrm{ab}$ & $26.86 \mathrm{a}$ & $5.89 \mathrm{a}$ & $199.72 \mathrm{ab}$ & $86.78 \mathrm{a}$ \\
\hline Azul & $0.23 \mathrm{~b}$ & $0.49 \mathrm{~b}$ & $25.90 \mathrm{ab}$ & $33.94 \mathrm{ab}$ & $26.84 \mathrm{a}$ & $5.96 \mathrm{a}$ & $204.86 \mathrm{ab}$ & $74.33 \mathrm{ab}$ \\
\hline Tandil & $0.30 \mathrm{ab}$ & $0.52 \mathrm{ab}$ & $28.56 \mathrm{a}$ & $36.81 \mathrm{a}$ & $28.91 \mathrm{a}$ & $6.15 \mathrm{a}$ & $221.95 \mathrm{a}$ & $77.08 \mathrm{ab}$ \\
\hline Ayacucho & $0.31 \mathrm{ab}$ & $0.60 \mathrm{ab}$ & $24.82 \mathrm{~b}$ & $32.24 \mathrm{ab}$ & $27.85 \mathrm{a}$ & $6.59 \mathrm{a}$ & $203.34 \mathrm{ab}$ & $80.38 \mathrm{ab}$ \\
\hline \multicolumn{9}{|c|}{$100 \mathrm{mM} \mathrm{NaCl}$} \\
\hline & LMS & RMS & $\mathrm{LL}$ & SL & RL & NL & SDM & $\mathrm{RDM}$ \\
\hline Lobos & $0.39 \mathrm{a}$ & $0.58 \mathrm{ab}$ & $27.14 \mathrm{ab}$ & $36.01 \mathrm{a}$ & $26.34 \mathrm{a}$ & $6.04 \mathrm{a}$ & $188.44 \mathrm{a}$ & $71.43 \mathrm{a}$ \\
\hline
\end{tabular}


Continued

\begin{tabular}{ccccccccc}
\hline R. Perez & $0.35 \mathrm{a}$ & $0.54 \mathrm{ab}$ & $25.06 \mathrm{ab}$ & $33.38 \mathrm{ab}$ & $24.39 \mathrm{a}$ & $6.02 \mathrm{a}$ & $187.45 \mathrm{a}$ & $75.22 \mathrm{a}$ \\
Saladillo & $0.37 \mathrm{a}$ & $0.55 \mathrm{ab}$ & $27.60 \mathrm{ab}$ & $36.57 \mathrm{a}$ & $28.83 \mathrm{a}$ & $6.30 \mathrm{a}$ & $203.41 \mathrm{a}$ & $96.28 \mathrm{a}$ \\
Azul & $0.38 \mathrm{a}$ & $0.49 \mathrm{~b}$ & $26.63 \mathrm{ab}$ & $34.04 \mathrm{ab}$ & $26.11 \mathrm{a}$ & $5.80 \mathrm{a}$ & $198.40 \mathrm{a}$ & $89.67 \mathrm{a}$ \\
Tandil & $0.34 \mathrm{a}$ & $0.51 \mathrm{~b}$ & $28.75 \mathrm{a}$ & $36.51 \mathrm{a}$ & $28.24 \mathrm{a}$ & $5.96 \mathrm{a}$ & $230.98 \mathrm{a}$ & $88.68 \mathrm{a}$ \\
Ayacucho & $0.44 \mathrm{a}$ & $0.62 \mathrm{a}$ & $23.76 \mathrm{~b}$ & $30.42 \mathrm{~b}$ & $26.17 \mathrm{a}$ & $6.11 \mathrm{a}$ & $184.31 \mathrm{a}$ & $83.31 \mathrm{a}$ \\
\hline
\end{tabular}

Different letters indicate significant differences between population, at $\mathrm{p}<0.05$ (Tukey's Test).

Table 5. Phenotypic correlation coefficients between the traits measured in the $0 \mathrm{mM}$ $\mathrm{NaCl}$ treatment (below diagonal) and $100 \mathrm{mM} \mathrm{NaCl}$ treatment (above diagonal). Leaf cell membrane stability (LMS, ratio), Root cell membrane stability (RMS, ratio), Shoot length $(\mathrm{SL}, \mathrm{cm})$, Root length (RL, cm), Leaf length (LL, cm), Number leaf (NL, number), Shoot dry mass (SDM, mg) and Root dry mass (RDM, mg).

\begin{tabular}{|c|c|c|c|c|c|c|c|c|c|}
\hline & \multicolumn{9}{|c|}{$0 \mathrm{mM} \mathrm{NaCl}$} \\
\hline \multirow{9}{*}{ 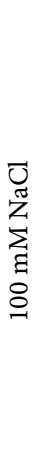 } & & LMS & RMS & LL & SL & $\mathrm{RL}$ & NL & SDM & $\mathrm{RDM}$ \\
\hline & LMS & 1 & $0.89^{* *}$ & $0.44^{\star *}$ & $0.34^{* *}$ & $0.19 \mathrm{~ns}$ & $0.10 \mathrm{~ns}$ & $0.13 \mathrm{~ns}$ & $0.54^{* *}$ \\
\hline & RMS & $0.77^{\star *}$ & 1 & $0.09 \mathrm{~ns}$ & $0.02 \mathrm{~ns}$ & $-0.01 \mathrm{~ns}$ & $0.13 \mathrm{~ns}$ & $-0.06 \mathrm{~ns}$ & $0.41^{\star *}$ \\
\hline & $\mathrm{LL}$ & $-0.69^{\star *}$ & $-0.56^{\star *}$ & 1 & $0.98^{\star *}$ & $0.67^{\star \star}$ & $-0.14 \mathrm{~ns}$ & $0.72^{\star *}$ & $0.64^{\star *}$ \\
\hline & SL & $-0.69^{* *}$ & $-0.45^{\star *}$ & $0.95^{\star *}$ & 1 & $0.78^{\star \star}$ & $0.09 \mathrm{~ns}$ & $0.84^{\star *}$ & $0.72^{\star *}$ \\
\hline & $\mathrm{RL}$ & $-0.2 \mathrm{~ns}$ & $-0.09 n s$ & $0.71^{\star *}$ & $0.62^{\star \star}$ & 1 & $0.67^{\star *}$ & $0.98^{\star *}$ & $0.81^{\star *}$ \\
\hline & NL & $0.22 \mathrm{~ns}$ & $0.62^{\star \star}$ & $-0.06 \mathrm{~ns}$ & $0.11 \mathrm{~ns}$ & $0.44^{\star *}$ & 1 & $0.56^{\star *}$ & $0.49^{\star *}$ \\
\hline & SDM & $-0.69^{\star *}$ & $-0.59^{\star *}$ & $0.81^{\star *}$ & $0.63^{\star *}$ & $0.69^{\star *}$ & $-0.13 n s$ & 1 & $0.82^{\star *}$ \\
\hline & $\mathrm{RDM}$ & $-0.16 \mathrm{~ns}$ & $-0.37^{\star *}$ & $0.37^{\star *}$ & $0.23 \mathrm{~ns}$ & $0.76^{* *}$ & $0.21 \mathrm{~ns}$ & $0.69^{\star *}$ & 1 \\
\hline
\end{tabular}

${ }^{*}$ Significant at the 0.05 probability level, ${ }^{*}$ Significant at the 0.01 probability level and ns not significant.

Correlation coefficients between membrane stability traits (LMS and RMS) and morphological ones were mostly significant and negative at $100 \mathrm{mM} \mathrm{NaCl}$; while they were significant and positive at $0 \mathrm{mM}$.

The correlations between RDM versus morphological variables were all significant at $0 \mathrm{mM} \mathrm{NaCl}$. However, in the saline treatment the majority were not significant and only SDM $(r=0.55), \mathrm{RL}(\mathrm{r}=0.73)$ and LL $(0.37)$ showed significant correlations. Another interesting difference in correlations can be seen between SDM vs $\mathrm{NL}$ that was positive and significant at $0 \mathrm{mM} \mathrm{NaCl}(\mathrm{r}=0.56)$, while in salt it was negative and not significant $(r=-0.13)$. The $r$ values between morphological traits were higher in the treatment without salt; only two exceptions were observed between LL vs. RL, with $\mathrm{r}$ values: $0.71(\mathrm{p}<0.01)$ and $0.67(\mathrm{p}$ $<0.01)$, and LL vs SDM with r: $0.81(\mathrm{p}<0.01)$ and $0.72(\mathrm{p}<0.01)$, for $100 \mathrm{mM}$ and $0 \mathrm{mM} \mathrm{NaCl}$, respectively.

\subsection{Path Coefficient Analysis. Cause-Effect Model for $100 \mathrm{mM}$ $\mathrm{NaCl}$ Treatment}

The model selected by PCA $=$ considered to SDM as a dependent variable and two levels of independent variables were established. The first-order indepen- 
dent variables were: RL, SL, RDM, LL and NL, while RMS was considered as a second order one. There was a very good fit of the model in both treatments and the explained variability was higher at saline treatment than at $0 \mathrm{mM}$. In order to improve the fit of the diagram, several modifications were proposed. At first the incorporation of LMS into the model as a first-order variable allowed to probe a decrease in the residual, although it brought lower $\mathrm{R}^{2}$ values, consequently, the model of five independent variables was maintained. The elimination of NL was also considered, since it presented a low and no significant $r$ value $(-0.13)$ with respect to SDM. Direct and indirect effects on SDM did not improve when NL was eliminated from the model, and thus the residue value increased from $4 \%$ to $31 \%$. Probably a nonlinear association between the variables could exist, as consequence; it was included to assure a better fit.

PCA showed that the most of the total correlations between the dependent variable (SDM) and the independent ones reached similar values (in sign and magnitude) for both treatments, although almost always lower in the saline treatment (Table 6). Except LL that reached a higher value at salt which could indicate the importance of the leaf in the strategies of tolerance of the prairie grass.

The direct effects of the first order path showed higher values at salt in relation to the salt-free treatment. In addition, the variables SL and LL, which had the greatest, direct effects on SDM, presented opposite signs in both treatments (Table 6). The direct effects on salt were -4.65 via SL and 6.68 via LL; while in the trial without salt were 3.07 and -1.89 , respectively. In addition, in the treatment without salt no other variable reached so important direct effect on SDM. While, in salinity, the variables NL and RL also contributed with medium direct effects (1.62 and -2.11 , respectively).

The direct effect of RDM on SDM at saline treatment was low (0.36), however this trait mainly explained to the dependent variable by its indirect effects, rather than direct one (Table 6). Our results indicate that the increase in SDM is accompanied by an increase in leaf size via indirect effect of 2.47 , and of negative indirect effects via SL and RL with -1.07 and -1.54 values, respectively. Conversely, at salt-free treatment, RDM had an important and positive indirect effect via SL (2.22), indicating that the pseudostem is a strong source of accumulation of reserves, causing rapid weight gain.

The indirect effects of greater magnitude in salinity were those estimated via LL, SL and RL, reaching a positive sign for the first variable and negative for the rest (Table 6). These effects would define plants with longer leaves but with smaller roots and pseudostem. Thus NL only presents a positive medium direct effect (1.62) but no significant indirect effects. These associations probe that the strategy of increasing the photosynthesizing surface is sustained, either due to a larger size or a higher number of leaves. When compared to the salt-free treatment, either NL had no significant effects, which would indicate that the growth cycle was normally maintained. 
Table 6. Direct and indirect effects of Shoot length (SL, cm), Root length (RL, cm), Leaf Length (LL, cm), Number leaf (NL, number) and Root dry mass (RDM, mg) upon Shoot dry mass (SDM, mg) of prairie grass population seedling grown under saline and non-saline environment.

\begin{tabular}{|c|c|c|}
\hline \multirow{2}{*}{$\begin{array}{c}\text { Shoot Dry Masses } \\
\text { Type of effect }\end{array}$} & \multicolumn{2}{|c|}{ Environment } \\
\hline & Saline & Non saline \\
\hline \multicolumn{3}{|l|}{ Effect of Shoot Length } \\
\hline Direct effect & -4.65 & 3.07 \\
\hline Indirect effect via Root Length & -1.31 & -0.37 \\
\hline Indirect effect via Leaf Length & 6.33 & -1.84 \\
\hline Indirect effect via Number Leaf & 0.18 & 0.05 \\
\hline Indirect effect via Root Dry Masses & 0.08 & -0.07 \\
\hline Total correlation $(r)$ & 0.63 & 0.84 \\
\hline \multicolumn{3}{|l|}{ Effect of Root Length } \\
\hline Direct effect & -2.11 & -0.47 \\
\hline Indirect effect via Shoot Length & -2.88 & 2.42 \\
\hline Indirect effect via Leaf Length & 4.72 & -1.26 \\
\hline Indirect effect via Number Leaf & 0.71 & 0.38 \\
\hline Indirect effect via Root Dry Masses & 0.23 & -0.07 \\
\hline Total correlation $(r)$ & 0.69 & 0.98 \\
\hline \multicolumn{3}{|l|}{ Effect of LL } \\
\hline Direct effect & 6.68 & -1.89 \\
\hline Indirect effect via Shoot Length & -4.41 & 3.00 \\
\hline Indirect effect via Root Length & -1.50 & -0.32 \\
\hline Indirect effect via Number Leaf & -0.09 & -0.02 \\
\hline Indirect effect via Root Dry Masses & 0.13 & -0.06 \\
\hline Total correlation $(r)$ & 0.81 & 0.71 \\
\hline \multicolumn{3}{|l|}{ Effect of NL } \\
\hline Direct effect & 1.62 & 0.57 \\
\hline Indirect effect via Shoot Length & -0.52 & 0.27 \\
\hline Indirect effect via Root Length & -0.92 & -0.32 \\
\hline Indirect effect via Leaf Length & -0.38 & 0.08 \\
\hline Indirect effect via Root Dry Masses & 0.07 & -0.04 \\
\hline Total correlation $(r)$ & -0.13 & 0.55 \\
\hline \multicolumn{3}{|l|}{ Effect of Root Dry Masses } \\
\hline Direct effect & 0.36 & -0.09 \\
\hline Indirect effect via Shoot Length & -1.07 & 2.22 \\
\hline Indirect effect via Root Length & -1.54 & -0.38 \\
\hline Indirect effect via Leaf Length & 2.47 & -1.20 \\
\hline Indirect effect via Number Leaf & 0.33 & 0.27 \\
\hline Total correlation $(r)$ & 0.54 & 0.81 \\
\hline Coefficient of Determination $\left(\mathrm{R}^{2}\right)$ & 0.99 & 0.99 \\
\hline Residual effect & $0.04 \%$ & $0.015 \%$ \\
\hline
\end{tabular}


Considering the second order path in saline treatment (table no shown), the RMS had a negative and moderate influence on most of the variables, except on $\mathrm{NL}$, which reached a moderate and positive effect $(r=0.62)$. Furthermore, it was the variable that explained the highest percentage of the RMS phenotypic variation (39\%). The direct effect of RMS on SDM $(-0.59)$ was moderate and the variables that most affected SDM were LL, $\mathrm{LP}$ and $\mathrm{NH}$, with direct effects of -3.76 , 2.10 and 1.01, respectively. The other remaining variables presented low effects $(<1)$.

\section{Discussion}

The absence of significant interactions denotes a non-differential behavior of the populations towards salt (saline) and non-salt (non-saline) treatments, verifying a good homeostatic capacity of the prairie grass facing that abiotic stress. This pattern was also confirmed when the populations with better performance at 0 $\mathrm{mM}$ also were the best at $100 \mathrm{mM}$. Possibly these homeostatic responses are associated with specific adaptations to local conditions which were also confirmed in other species of Bromus [20].

The saline stress caused a pairing in the population means for the vegetative traits. The resulting coefficients of variation were mainly higher when the seedlings grew without stress $(0 \mathrm{mM})$ because it allowed a greater potential genotypic expression [29]. [30] pointed in salt tolerant grasses (Subfamily Chloridoideae) an increasing for root length and root weight under extreme saline condition $(600 \mathrm{mM})$, relative to control. Even though the used saline concentrations were much lower, our results also showed an increase for leaf and shoot length at salt. [31] investigated the growth patterns of cheat-grass (Bromus tectorum L.) and demonstrated that plants collected from saline sites, accumulated leaf and root area at nearly twice the rate from no saline sites, even in the control group.

Variables associated with membrane stability (LMS and RMS) showed significant and negative correlations with the majority of the morphological variables within the saline treatment, while the result was not the same when nonsaline treatment was used. Being these variables of early identification, it would be highly important to employ them under a salt-stress breeding program [32].

Within the non-salt treatment, the high correlation coefficients obtained between RDM and the morphological variables, showed a balanced and harmonious growth between shoot and root organs. While regarding the saline treatment, the lack of significant correlations might show the presence of a different type of (nonlinear) association between the variables. It could be also explained as an alteration in the allocation of resources between shoot and root, due to stress, that would cause some changes in the growth patterns. Those changes in the assigned resources between aerial and roots parts were also mentioned by [8].

The positive correlation between RDM and RL $\left(r=0.73^{\star *}\right)$ would be expected for the saline treatment (Table 5). Thus, the correlation between RDM and SDM $\left(0.69^{* *}\right)$ might indicate a synchronized growth between shoot and root. Howev- 
er, it was associated neither to the increase of the aerial part growth nor to a major number of leaves, since no significant correlation was found between these variables. The lack of correlation between SDM and NL might indicate that the increase of the aerial part is associated with the increase in the size of the leaves and stem but not with the increase in the number of leaves. Our results seem to match with those obtained by [33], which would indicate a delay in growth associated with salt stress.

The non-saline treatment showed higher and significant correlations between the morphological variables in comparison with the saline one, with the exception of two correlations LL vs RL and LL vs SDM which reached higher values at saline stress (Table 5). A major leaf growth might be related with the development of a tolerant behavior towards saline stress. This result was also pointed by other authors [34] [35].

The direct effect is a standardized regression coefficient $\left(\rho 01=\mathrm{b} 1{ }^{\star} \sigma x 1 / \sigma y\right)$; which represents the independent variable effect $(x 1)$ over the dependent variable $(y)[16]$. By this, the highest $\rho$ values (direct effect) estimated in the saline treatment might be due to the presence of a higher standard deviation or phenotypic variability of the independent variable, which is exposed by the effects of salinity.

In saline treatment, the aerial dry matter production has been mainly due to the direct positive effect of LL (6.68), it can also be seen that NL showed a moderate direct effect (1.62). On the other hand, the $0 \mathrm{mM} \mathrm{NaCl}$ treatment didn't show the same growth pattern, being the SL one of the traits that best explained the variation of SDM (3.07). The obtained high salinity values would demonstrate the profound effect that this stress provokes on the measured characters, creating changes in the growth patterns to develop adaptation and survival strategies. The nature of the direct effects found, could be pointing a different destination of the photo assimilated substances for both treatments. In terms of salinity, there would be a greater destination towards the leaf blade production in order to maintain the photosynthetic surface that would allow a greater light absorption and carbon dioxide assimilation. A larger photosynthetic area in early stages of development could be the key to a rapid increase of SDM in the future [36].

Changes in the photo assimilated substances destination was also pointed out by [8] [9]. This alteration in the photosynthetic resources, allocated towards the leaf to the detriment of the root, is also verified by the high direct effects and opposite signs that NL and RL presented (1.62 and -2.11 , respectively). Changes in the resource distribution between the aerial part and the root were also noted under conditions stress by [8] [9] [37].

Also [38] point out the alteration of the photoassimilates destination in plants growing under stress and define the concept of functional growth, from which the plants seek to restore similar biomass distribution patterns to those developed in non-stress situations. It means that plants show a marked resilience.

Smooth Bromegrass (B. inermis Leyss) and other Bromus sp have been classi- 
fied as moderately salt tolerant, using the crop tolerance index given by [39] and [40]. Our results would include to prairie grass inside of the moderately salt tolerant group.

\section{Conclusions}

Our results indicate that populations, collected from differential sites from the Pampa Region, present intraspecific variability and carry tolerant genes which ensure a good adaptation to stressful environments. Therefore, it would be convenient to include these populations at the beginning of a plant breeding, shortening the selection time required to obtain adapted germplasm. These programs could include individual selection on the best populations, prioritizing seed and forage yield.

Plants in the salt-free treatment would produce an increase in the SDM from a larger size of the internodes and pods that constitute the pseudostem and not by an increase in leaf length. In contrast, in salinity, the increase in SDM is related to the active growth of leaves, and a lesser development of internodes and sheaths that determines a smaller pseudostem. In salinity, plants would maintain the photosynthesizing surface and consequently, prioritize the growth of the leaves and not of the pseudostem or the root.

In salt conditions, some populations evidence a notable increase in foliar development and it allows maintaining the photosynthetic surface and an active growth. In this way, the same biomass obtained in non-saline stress is sustained. As prairie grass is used as forage, we can use this foliar increase (resilience) as an interesting and valuable strategy to use in improvement programs.

\section{Conflicts of Interest}

The authors declare no conflicts of interest regarding the publication of this paper.

\section{References}

[1] Lavado, R.S. and Taboada, M.A. (2017) Génesis y propiedades de los suelos halomórficos. In: Taleisnik, E. and Lavado, R.S., Eds., Ambientes salinos y alcalinos de la Argentina. Recursos y aprovechamiento productivo, Orientación gráfica Editora, Universidad Católica de Córdoba, Buenos Aires, 55-88.

[2] Sánchez, R.M., Guerra, L.D. and Scherger M. (2016) Evaluación de las áreas bajo riego afectadas por salinidad y/o sodicidad en Argentina. 1a ed., Hilario Ascasubi, Ediciones INTA, Libro Digital, Buenos Aires, 74 p.

[3] Rengasamy, P. (2006) World Salinization with Emphasis on Australia. Journal of Experimental Botany, 57, 1017-1023. https://doi.org/10.1093/jxb/erj108

[4] Taleisnik, A., Grunberg, K. and Santa Maria, G. (2008) La salinización de suelos en la Argentina: Su impacto en la producción agropecuaria [Soil Salinization in Argentina: Impact on Crop and Livestock Production]. Editorial Universitaria de Córdoba.

[5] Imbellone, P.A., Giménez, J.E. and Panigatti, J.L. (2010) Procesos de sodificación y salinización. Suelos de la región pampeana. Procesos de Formación. INTA, Buenos 
Aires, 261-288.

[6] Shabala, S. and Munns, R. (2012) Salinity Stress: Physiological Constraints and Adaptive Mechanisms. In: Shabala, S., Ed., Plant Stress Physiology, CAB International, Oxford, 59-93. https://doi.org/10.1079/9781845939953.0059

[7] Munns, R. and Gilliham, M. (2015) Salinity Tolerance of Crops-What Is the Cost? New Physilolgist, 208, 668-673. https://doi.org/10.1111/nph.13519

[8] Greenway, H. and Munns, R. (1980) Mechanisms of Salt Tolerance in Nonhalophytes. Plant Physiology, 31, 149-190. https://doi.org/10.1146/annurev.pp.31.060180.001053

[9] Silva de Aquino, A.J., Feitosa de Lacerda, C., Bezerra, M., Gomez Filho, E. and Távora Costa, R.N. (2007) Growth, Dry Mass Partitioning, and $\mathrm{Na}^{+}, \mathrm{K}^{+}$, and $\mathrm{Cl}^{-} \mathrm{Re}-$ tention by Two Sorghum Genotypes Irrigated with Saline Water. Revista Brasileira de Ciência do Solo, 31, 961-971. https://doi.org/10.1590/S0100-06832007000500013

[10] Tester, M. and Bacic, A. (2005) Abiotic Stress Tolerance in Grasses. From Model Plants to Crop Plants. Plant Physiology, 137, 791-793.

https://doi.org/10.1104/pp.104.900138

[11] Rosso, B., Pagano, E., Rimieri, P. and Ríos, R. (2009) Characteristics of Bromus catherticus Vahl. (Poaceae) Natural Populations Collected in the Central Area of Argentina. Scientia Agricola (Piracicaba, Braz.), 66, 276-279.

https://doi.org/10.1590/S0103-90162009000200019

[12] Ali, Q., Shahid, S., Hussain, A.I., Shehzad, F., Perveen, R., Habib, N., Ali, S., Iqbal, N., Waseem, M. and Hussain, S.M. (2020) Breeding Plants for Future Climates. In: Hasanuzzaman, M., Ed., Plant Ecophysiology and Adaptation under Climate Change: Mechanisms and Perspectives I, Springer, Singapore, 753-795. https://doi.org/10.1007/978-981-15-2156-0_27

[13] Cicek, N. and Cakirlar, H. (2002) The Effect of Salinity on Some Physiological Parameters in Two Maize Cultivars. Bulgarian Journal of Plant Physiology, 28, 66-74.

[14] Ashraf, M. (2004) Some Important Physiological Selection Criteria for Salt Tolerance in Plants. Flora: Morphology, Distribution, Functional Ecology of Plants, 199, 361-376. https://doi.org/10.1078/0367-2530-00165

[15] Ashraf, M. and Harris, P.I. (2004) Potential Biochemical Indicators of Salinity Tolerance in Plants. Plant Sciences, 166, 3-16. https://doi.org/10.1016/j.plantsci.2003.10.024

[16] Li, C.C. (1975) Path Analysis: A Primer. Boxwood Press, Pacific Grove, CA.

[17] Andrés, A. (2005) El mejoramiento genético de las especies forrajeras. Manual de Pasturas. Bayer Crop Science, 5-10. E.E.A INTA Pergamino.

http://www.produccionanimal.com.ar

[18] Aulicino, M.B. and Arturi, M.J. (2002) Phenotypic Diversity in Argentinean Populations of Bromus catharticus (Poaceae). Genetic and Environmental Components of Quantitative Traits. New Zealand Journal of Botany, 40, 223-234. https://doi.org/10.1080/0028825X.2002.9512785

[19] Aulicino, M.B. and Arturi, M.J. (2008) Regional Variation in Argentinean Populations of Bromus catharticus (Poaceae) as Measured by Morphological. Anales del Jardín Botánico de Madrid, 65, 135-147.

[20] Ashraf, M., Athar, H.R., Harris, P.J.C. and Kwon, T.R. (2008) Some Prospective Strategies for Improving Crop Salt Tolerance. Advances in Agronomy, 97, 45-110. https://doi.org/10.1016/S0065-2113(07)00002-8

[21] Marshall, D.R. and Brown, A.H.D. (1975) Optimum Sampling, Strategies in Genetic 
Conservation. In: Frankel, O.H. and Hawkes, J.G., Eds., Crop Genetic Resources for Today and Tomorrow, Cambridge University Press, Cambridge, 53-80.

[22] Rao, S.A. and McNeilly, T. (1999) Genetic Basis of Variation for Salt Tolerance in Maize (Zea mays L). Euphytica, 108, 145-450.

https://doi.org/10.1023/A:1003612411293

[23] Khan, A.A. and McNeilly, T. (2005) Triple Test Cross Analysis for Salinity Tolerance Based upon Seedling Root Length in Maize (Zea mays L.). Breeding Science, 55, 321-325. https://doi.org/10.1270/jsbbs.55.321

[24] Mansour, M.M. and Salama, K.H. (2004) Cellular Basis of Salinity Tolerance in Plants. Environmental and Experimental Botany, 52, 113-122.

https://doi.org/10.1016/j.envexpbot.2004.01.009

[25] Mansour, M.M., Salama, K.H., Ali, F.Z. and Abou Hadid, A.F. (2005) Cell and Plant Response to $\mathrm{NaCl}$ in Zea mays L. Cultivars Differing in Salt Tolerance. General and Applied Plant Physiology, 31, 29-41.

[26] Nyquist, W.E. and Baker, R.J. (1991) Estimation of Heritability and Prediction of Selection Response in Plant Populations. Critical Reviews in Plant Sciences, 10, 235-322. https://doi.org/10.1080/07352689109382313

[27] Sokal, R.R. and Rohlf, F.J. (1995) Biometry. W.H. Freeman and Co., New York, 887 p.

[28] Cruz, C.D. (2001) Programa Genes: Versao Windows, aplicativo computacional em genética e estadística. UFV Viçosa, Brasil, 648 p.

[29] Fernandez, G.C.J. (1992) Effective Selection Criteria for Assessing Plant Stress Tolerance. Proceeding of Symposium, Taiwan, 13-16 August 1992, Chapter 25.

[30] Kenneth, B.M. (1999) Salinity Tolerance Mechanisms of Grasses in the Subfamily Chloridoideae. Crop Science, 39, 1153-1160. https://doi.org/10.2135/cropsci1999.0011183X003900040034x

[31] Rasmuson, K.E. and Anderson, J.E. (2002) Salinity Affects Development, Growth, and Photosynthesis Cheatgrass. Journal of Range Management, 55, 80-87. https://doi.org/10.2307/4003267

[32] Collado, M.B., Arturi, M.J., Aulicino, M.B. and Molina, M.C. (2010) Identification of Salt Tolerance in Seedling of Maize (Zea mays L.) with the Cell Membrane Stability Trait. International Research Journal of Plant Science, 1, 126-132.

[33] Munns, R. (2005) Genes and Salt Tolerance: Bringing Them Together. New Phytologist, 167, 645-663. https://doi.org/10.1111/j.1469-8137.2005.01487.x

[34] Richards, R.A. (1996) Defining Selection Criteria to Improve Yield under Drought. Plant Grow Regulation, 20, 157-166. https://doi.org/10.1007/BF00024012

[35] López-Castañeda, C. and Richards, R.A. (1994) Variation in Temperate Cereals in Rainfed Environments. II. Phasic Development and Growth. Field Crops Research, 37, 63-75. https://doi.org/10.1016/0378-4290(94)90082-5

[36] Sanderson, M.A., Stair, D.W. and Hussey, M.A. (1997) Physiological and Morphological Responses of Perennial Forages to Stress. Advances in Agronomy, 59, 171-224. https://doi.org/10.1016/S0065-2113(08)60055-3

[37] Poorter, H., Niklas, K., Reich, P., Oleksyn, J., Poot, P. and Mommer, L. (2012) Biomass Allocation to Leaves, Stems and Roots: Meta-Analyses of Interspecific Variation and Environment Control. New Phytologist, 193, 30-50. https://doi.org/10.1111/j.1469-8137.2011.03952.x

[38] Poorter, H. and Nagel, O. (2000) The Role of Biomass Allocation in the Growth of Plants to Different Levels of Light, $\mathrm{CO}_{2}$, Nutrients and Water: A Quantitative Re- 
view. Australian Journal of Plant Physiology, 27, 595-607.

https://doi.org/10.1071/PP99173

[39] Maas, E.V. and Hoffman, G.J. (1977) Crop Salt Tolerance: Current Assessment. Journal of the Irrigation and Drainage Division, 103, 115-134.

[40] Grieve, C.M., Grattan, S.R. and Maas, E.V. (2012) Plant Salt Tolerance. In: Wallender, W.W. and Tanji, K.K., Eds., Agricultural Salinity Assessment and Management, 2nd Edition, Chapter 13, ASCE, Reston, VA, 405-459.

https://doi.org/10.1061/9780784411698.ch13 